\title{
Livestock Production System and Their Constraints in West Arsi Zone, Oromia National Regional State, Ethiopia
}

\author{
Yassin Esmael Ahmed*, Beriso Bati Bukul, Shemalis Gizachew, Asfew Negase Sanbate \\ Socio-Economics Research Team, Adami Tulu Agricultural Research Centre, Adami Tulu, Ethiopia \\ Email address: \\ yasoesmael@gmail.com (Y. E. Ahmed), batiberis@gmail.com (B. B. Bukul), shimegiz2006@gmail.com (S. Gizachew), \\ bonsahu@gmail.com (A. N. Sanbate) \\ ${ }^{*}$ Corresponding author
}

\section{To cite this article:}

Yassin Esmael Ahmed, Beriso Bati Bukul, Shemalis Gizachew, Asfew Negase Sanbate. Livestock Production System and Their Constraints in West Arsi Zone, Oromia National Regional State, Ethiopia. International Journal of Biomedical Science and Engineering.

Vol. 7, No. 4, 2019, pp. 79-84. doi: 10.11648/j.ijbse.20190704.11

Received: August 14, 2019; Accepted: September 29, 2019; Published: October 12, 2019

\begin{abstract}
A livestock production system is a group of farm operations with approximately the same characteristics of climatic conditions and farming practices. Farm type identification helps to identify area specific problems and give proper technological intervention to address the problems. Therefore, this study was initiated to identify the livestock production systems and their constraints in West Arsi Zone. Both Primary and secondary data collection method was used to collect data. Secondary data was collected from Zone and concerned district offices using checklists. In addition to this, published and unpublished materials are also used as sources of secondary data. Multi-stage sampling technique was employed to select representative districts, kebeles and sample households. Focus group discussion (FGD), key informant interview and household direct interviews by using semi-structured questionnaires are used to collect primary data. A total of 264 sample households are selected to collect primary data. Descriptive statistics was used to analyze the collected data using STATA version 14. The study result identified livestock production system was classified mixed rainfall sufficient (MRS) which cattle, equine and sheep production system dominantly practiced and mixed rainfall deficit (MRD) which goat, beekeeping and backyard poultry production system majorly practiced. The major livestock production constraints like lack of access to credit services, shortage of improved breed, lack of livestock technologies, shortage of feed, disease, and climate change were identified and the possible policy implications were suggested to address the problems.
\end{abstract}

Keywords: Livestock, Production System, Classification, Production Constraints, Households, West Arsi Zone

\section{Introduction}

\subsection{Background and Justification}

Ethiopia has the largest livestock population in Africa and the tenth largest in the world [1]. Livestock currently contribute about 30 percent of agricultural gross domestic product in developing countries, with a projected increase to about 40 percent by 2030 [2, 3]. A livestock production system is a group of farm operations with approximately the same characteristics of climatic conditions and farming practices (i.e. the combination of land/herd, labour and capital) [4]. It takes a considerable part in the country's national income by providing products and by-products in the form of meat, milk, honey, eggs, cheese, and butter [5]. The animal products improve the nutritional status of the people. Livestock also plays an important role in providing export commodities, such as live animals, hides, and skins to earn foreign exchanges to the country [6]. On the other hand, draught animals provide power for the cultivation of the smallholdings and for crop threshing virtually all over the country and are also essential modes of transport to take holders and their families long-distances, to convey their agricultural products to the market places and bring back their domestic necessities. Livestock confer a certain degree of security in times of crop failure, as they are a "near-cash" capital stock. Furthermore, livestock provides farmyard manure that is commonly applied to improve soil fertility and also used as a source of energy [6].

Livestock production systems in Ethiopia are generally 
subsistence oriented and productivity is very low [7]. Despite the highest population, the productivity of livestock is low and not market-oriented compared to its potential, so the direct contribution to the national economy is limited [8]. Due to the low productivity of the animals and, the volume of marketed surplus is very low [9]. Low productivity occurred due to shortage of feed, drought, disease occurrence and lack of improved livestock technologies like artificial insemination, health service and shortage of improved breed. Under such conditions it would be hard to expect the livestock sector to play positive roles that contribute to attain sustainable livelihoods of the farming and pastoral communities in West Arsi Zone in particular and in the country in general. Therefore, this study was initiated to classify, identify livestock production systems, and prioritize livestock production constraints and recommend area of intervention in West Arsi Zone.

\subsection{Objectives of the Study}

To identify the livestock production systems

To identify and prioritize livestock production constraints in the study areas

\section{Research Methodology}

\subsection{Description of the Study Areas}

The study was conducted in West Arsi Zone, Oromia National Regional State, Ethiopia. West Arsi Zone lies between $6^{\circ} 00^{\prime} \mathrm{N}$ to $7^{\circ} 35^{\circ} \mathrm{N}$ and $38^{\circ} 00^{\prime} \mathrm{E}$ to $40^{\circ} 00^{\prime} \mathrm{E}$ and demarcated by Bale Zone in west direction, Arsi Zone in East direction, Southern Nation Nationality and People Regional State in South direction, and East Shewa Zone in north direction. Shashemena city is the capital city of West Arsi Zone which located at $250 \mathrm{~km}$ from Addis Ababa towards South direction [10].

West Arsi Zone encompasses different agro-ecologies namely high land, midland and lowland. In the Zone the high land agro-ecology (47.92\%) took more coverage followed by midland (42.50\%) and lowland (9.82\%) agro-ecologies. The Zone lies within altitude of 1500-3800 meter above sea level [10].

The total population in the Zone was 2,290,280 of which $45.50 \%$ are male and $50.50 \%$ are female. The Zone was received $600 \mathrm{~mm}-2700 \mathrm{~mm}$ annual rain fall and has a bimodal pattern of rain fall. It was also received $12^{\circ} \mathrm{C}-27^{\circ} \mathrm{C}$ annual temperature per year. The Zone has a total of $1,286,277.50$ hectare of land. From the total land, $0.36 \%$ is arable land, $29.27 \%$ cultivated land, $19.50 \%$ forest land, $17.05 \%$ grazing land, $4.58 \%$ used for construction and $29.26 \%$ used for other purposes [10].

\subsection{Sampling Procedures and Sample Size}

Multi-stage sampling procedure was applied to select representative livestock rearing districts, kebeles and sample households in West Arsi Zone. On the basis of agro-ecologies (highland, midland and lowland) diversity, representative districts, Kebeles and sample household was selected using systematic sampling technique based livestock production potentials. From the selected Kebeles, sample households randomly selected for data collection using probability proportional to size. A multi-disciplinary team was formed to collect survey using different PRA tools like direct interview, focus group discussions and personal observations to collect data on different aspects of livestock production system and their constraints in the study area. Focus group discussion (FGD) and key informant interview employed to get the existing livestock production system, prevailing constraints and opportunities in the study areas. One FGD was undertaken per each selected district to collect data. A total of 8-10 farmers were selected based on their elder in the community, livestock production experience, gender, and educational background to conduct FGD and discussion was also made with concerned experts and Development agents at each selected Kebeles to conduct key informants interview. Finally, 264 sample households were selected for primary data collection from West Arsi Zone.

Table 1. Number of sample households in West Arsi Zone.

\begin{tabular}{lll}
\hline Names of Districts & Frequency & Percentage \\
\hline Kofale & 58 & 21.97 \\
Shala & 46 & 17.42 \\
Gadeb Hasasa & 82 & 31.06 \\
Shashemene & 78 & 29.55 \\
Total & 264 & 100 \\
\hline
\end{tabular}

\subsection{Types of Data, Sources and Method of Data Collection}

Both primary and secondary data was collected from different sources at different levels. Primary data was collected through focus group discussions, key informant interview and direct households interview using checklist and semi-structured questionnaire.

Secondary data was collected from different agricultural and natural resource development offices, livestock agency, trade and market development office at different levels (Zones, districts, and Kebeles), different NGOs and stakeholders working in the areas, CSA reports, and different un published reports.

\subsection{Methods of Data Analysis}

The collected data was analyzed using STATA version 14 software. The quantitative and qualitative data was analyzed using descriptive statistics like mean, standard deviations, frequency, and chi-square test to describe data and see the relationship between variables. The qualitative data collected through FGD and KII was also analyzed by narrating methods.

\section{Results and Discussion}

\subsection{Households Socio-demographic Characteristics}

Socio-demographic factors play a crucial role in livestock the production system. The socio-demographic factors are 
age of household heads, marital status, education background, family size, land holding and participation in off/Non-farm activities.

The study result indicated that the majority (92\%) of the sample households are male headed. Around $77 \%$ of the sample households are attended formal education followed by illiterate $(22 \%)$ in the study area (Table 2$)$. From the total sampled households, about $94 \%$ were married and the remaining $6 \%$ were unmarried, widowed and divorced.

Table 2. Socio-demographic variables of sample households.

\begin{tabular}{|c|c|c|c|c|c|c|c|c|c|c|c|}
\hline \multirow{3}{*}{ Variables } & \multirow{3}{*}{ Category } & \multicolumn{10}{|c|}{ Districts } \\
\hline & & \multicolumn{2}{|c|}{ Kofale $(n=58)$} & \multicolumn{2}{|c|}{ Shala $(n=46)$} & \multicolumn{2}{|c|}{ G/Hasada $(n=82)$} & \multicolumn{2}{|c|}{$\begin{array}{l}\text { Shashemene } \\
(n=78)\end{array}$} & \multicolumn{2}{|c|}{ Over all $(n=264)$} \\
\hline & & Freq & $\%$ & Freq & $\%$ & Freq & $\%$ & Freq & $\%$ & Freq & $\%$ \\
\hline \multirow{2}{*}{ Sex } & Male & 57 & 98.28 & 39 & 84.78 & 79 & 96.34 & 68 & 87.18 & 243 & 92.05 \\
\hline & Female & 1 & 1.72 & 7 & 15.22 & 3 & 3.66 & 10 & 12.82 & 21 & 7.95 \\
\hline \multirow{4}{*}{ Education status } & Illiterate & 7 & 12.07 & 8 & 17.39 & 26 & 31.71 & 17 & 21.79 & 58 & 21.97 \\
\hline & Read and write & & & & & 3 & 3.66 & & & 3 & 1.14 \\
\hline & Formal education & 48 & 82.76 & 38 & 82.61 & 52 & 63.41 & 60 & 76.93 & 198 & 75 \\
\hline & College/University & 3 & 5.17 & & & 1 & 1.22 & 1 & 1.28 & 5 & 1.89 \\
\hline \multirow{4}{*}{ Marital status } & Unmarried & & & 3 & 6.52 & 6 & 7.32 & 2 & 2.56 & 11 & 4.17 \\
\hline & Married & 58 & 100 & 40 & 86.96 & 75 & 91.46 & 74 & 94.87 & 247 & 93.56 \\
\hline & Widowed & & & 2 & 4.35 & & & 1 & 1.28 & 3 & 1.14 \\
\hline & Divorced & & & 1 & 2.17 & 1 & 1.22 & 1 & 1.28 & 3 & 1.14 \\
\hline
\end{tabular}

Sources: Household survey result, 2016.

The mean age and family size of the sampled households were 40 years and 8 person respective (Table 3 ). The mean landholding of the farm households was 2.06 hectare. Land is one of an important input in agricultural production. The study result revealed that the sampled households are allocated more lands for production purpose (Table 3). In addition to this, the respondent allocated lands for forest and grazing lands. The land degradation was also occurred due to miss-use of the land in the study areas (Table 3 ).

Table 3. Description of continues variables of sample households.

\begin{tabular}{llll}
\hline \multirow{2}{*}{ No. } & Variables & \multicolumn{2}{l}{ Over all $(\mathbf{n = 2 6 4 )}$} \\
\cline { 3 - 4 } & & Mean & Std. Dev. \\
\hline 1 & Age & 39.90 & 12.75 \\
2 & Total Family size & 8.23 & 3.61 \\
3 & Total land holding (ha) & 2.06 & 1.44 \\
4 & Total cultivated land (ha) & 1.60 & 1.10 \\
5 & Land for grazing (ha) & 0.25 & 0.33 \\
6 & Erosion affected land (ha) & 0.05 & 0.13 \\
7 & Forest land (ha) & 0.02 & 0.08 \\
8 & Homestead land (ha) & 0.24 & 0.16 \\
\hline
\end{tabular}

Sources: Household survey result, 2016.

\subsection{Households'Participation in Off/Non-Farm Activities}

The farmers in the study areas engaged in farm (crop and livestock) and off/non-farm activities to diversify their livelihoods. The Household's participated in off/non-farm activities in West Arsi to generate alternative income. The off/non-farm activities that households engaged to generate additional incomes are causal labor means working on others farm, trade, guarding, petty trade, and driving carts. The households participated more in trading (crop and livestock) to generate additional income in the study areas (Table 4).
Table 4. The type of off/non-farm activities performed in the study areas.

\begin{tabular}{lll}
\hline \multirow{2}{*}{ Off/non-farm activities } & \multicolumn{2}{l}{ Over all $(\mathbf{n = 2 6 4 )}$} \\
\cline { 2 - 3 } & Frequency & Percent \\
\hline Casual farm labor & 4 & 5.71 \\
Salaried worker as guard & 12 & 17.14 \\
Traders (crop and livestock) & 46 & 65.71 \\
Petty trade & 4 & 5.72 \\
Driving carts & 4 & 5.71 \\
\hline
\end{tabular}

Sources: Household survey result, 2016.

\subsection{Institutional Facilities in Livestock Production in West Arsi Zone}

The institutional factors play a crucial role to increase agricultural production. These institutional facilities are irrigation facilities, communication facilities, extension services, credit facilities and market services.

Credit service is an important factor that increases agricultural production. The majority $(67 \%)$ of the sample respondents had no access to credit services in the two years period around. The reasons were due to high interest rate, lack of collateral and religious influences. However, about $33 \%$ of the households had access to credit services and used credit for purchasing agricultural inputs (fertilizers, improved seeds, and chemicals), purchasing animals for fattening/breeding and for purchasing food for home consumption. The study areas, the households got credit from saving and credit association (40.40\%), microfinance institutions $(30 \%)$ and Non-governmental organizations $(17.17 \%)$ respectively. The chi square test indicated that there is a significance difference between credit users and nonusers at $1 \%$ significance level. This result showed that the households who have access to credit very few compared to those who have no access to credit services (Table 5). 
Table 5. Institutional facilities in the study areas.

\begin{tabular}{|c|c|c|c|c|c|c|c|c|c|c|c|c|}
\hline \multirow{3}{*}{ Variables } & \multirow{3}{*}{ Response } & \multicolumn{10}{|c|}{ Districts } & \multirow{3}{*}{$\begin{array}{l}\chi^{2}- \\
\text { value }\end{array}$} \\
\hline & & \multicolumn{2}{|c|}{ Kofele $(n=58$} & \multicolumn{2}{|c|}{ Shala $(n=46)$} & \multicolumn{2}{|c|}{ G/Hasasa $(n=82)$} & \multicolumn{2}{|c|}{ Shashemene $(n=78)$} & \multicolumn{2}{|c|}{ Overall $(n=264)$} & \\
\hline & & Freq & $\%$ & Freq & $\%$ & Freq & $\%$ & Freq & $\%$ & Freq & $\%$ & \\
\hline \multirow{2}{*}{ Credit services } & No & 48 & 82.76 & 36 & 78.26 & 68 & 82.93 & 26 & 33.33 & 178 & 67.43 & \multirow{2}{*}{$58.9^{* * *}$} \\
\hline & Yes & 10 & 17.24 & 10 & 21.74 & 14 & 17.07 & 52 & 66.67 & 86 & 32.58 & \\
\hline \multirow{2}{*}{ Extension services } & No & 48 & 82.76 & 43 & 93.48 & 78 & 95.12 & 67 & 29.49 & 65 & 89.39 & \multirow{2}{*}{$7.34^{*}$} \\
\hline & Yes & 10 & 17.24 & 3 & 6.52 & 4 & 4.88 & 11 & 14.10 & 28 & 10.61 & \\
\hline \multirow{2}{*}{ Market information } & No & 14 & 24.14 & 9 & 19.57 & 19 & 23.17 & 23 & 85.90 & 236 & 24.62 & \multirow{2}{*}{1.73} \\
\hline & Yes & 44 & 75.86 & 37 & 80.43 & 63 & 76.83 & 55 & 70.51 & 199 & 75.38 & \\
\hline
\end{tabular}

***,*: indicated statistical significance at $1 \%$ and $10 \%$ levels

Extension service is another institutional factor that affects agricultural production in general and livestock production in particular in the areas. Table 5 above indicated that the majority $(89 \%)$ of the households do not get extension services on livestock production in study areas. Most of the farmers got extension advices from development agents (93.42\%), development agents and research center (4.18\%), and development agents and NGOs $(1.77 \%)$ in the study areas. The chi square test indicated that there is a significance difference between getting extension services and not getting extension service at $10 \%$ significance level. This result showed that the households who are getting extension services on livestock production is less than those who do not get extension services (table 5).

In the study areas, the majority (75\%) the households received market information in West Arsi Zone (table 5). The major sources of market information in West Arsi Zone were traders $(28.46 \%)$, traders and neighboring farmers (18.29\%), and neighboring farmers $(16.26 \%)$ followed by union $(1.22 \%)$ and cooperatives $(1.22 \%)$.

\subsection{Livestock Production System in West Arsi Zone}

A livestock production system is a group of farm operations with approximately the same characteristics of climatic conditions and farming practices (i.e. the combination of land/herd, labour and capital) [4]. Based on integration of livestock with crop production, level of input and intensity of production, agro-ecology and market orientation, livestock production system in Ethiopia is categorized as pastoral, agro-pastoral, mixed crop-livestock farming, urban and peri-urban farming and specialized intensive farming systems [11]. However, the livestock production systems are predominately categorized as agropastoral system in the lowland and the mixed crop-livestock system in the highlands [12].

The livestock production system in West Arsi Zone, classified based agro-ecological conditions of the areas basically based on the mixed rainfall deficient (MRD) and the mixed rainfall sufficient (MRS) systems. The MRD mainly concerns the lower areas with lower precipitation like Shashemene and Shala Districts. The mixed rainfall sufficient (MRS) systems cover much of the higher elevation areas with higher biophysical potential, as well as better infrastructure (market access). According to this classification, MRS is dominant in cattle, equine and sheep production system whereas MRD is dominant in goat, beekeeping and backyard poultry production system.

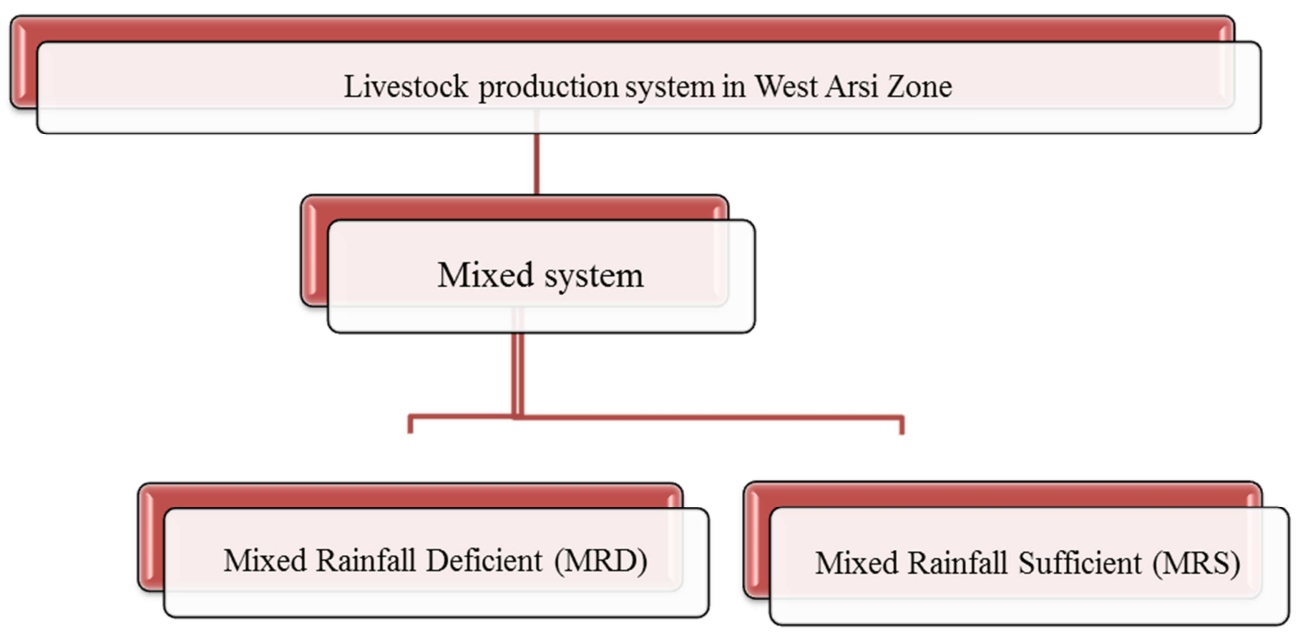

Figure 1. Classification of livestock production system in West Arsi Zone.

However, there is difference in livestock possession among households based on climatic condition and intensity of crop farming across districts. The major livestock type owned was cattle with mean of 9.15 followed by poultry and sheep 
having the mean of 8.47 and 4.2 respectively. Overall, West Arsi Zone has an average of 10.74 total livestock unit (TLU) that indicated there is still livestock production even though, its trends decreasing since last five years as $87.40 \%$ farmers perceived.

As the study result revealed that, in addition to free grazing $93.56 \%$ of sample households used crop residues such as wheat and barley bran for their livestock feeding. Moreover, the above feeding system (utilization of crop residue) is due to shrinkage of grazing land as $94.70 \%$ sample respondent perceived.

Table 6. Livestock owned in the study areas of West Arsi Zone.

\begin{tabular}{lllll}
\hline No & Livestock type & Amount & $\begin{array}{l}\text { Conversion } \\
\text { factor }\end{array}$ & $\begin{array}{l}\text { Converted in } \\
\text { TLU }\end{array}$ \\
\hline 1 & Local Cows & 2.49 & 1.0 & 2.49 \\
2 & Cross breed cows & 0.803 & 1.0 & 0.803 \\
3 & Local Oxen & 1.81 & 1.0 & 1.81 \\
4 & Heifers & 1.61 & 0.75 & 1.21 \\
5 & Calf & 1.60 & 0.25 & 0.40 \\
6 & Bulls & 0.84 & 0.75 & 0.63 \\
7 & Goat & 2.88 & 0.13 & 0.37 \\
8 & Sheep & 4.2 & 0.13 & 0.546 \\
9 & Local chicken & 5 & 0.013 & 0.065 \\
10 & Exotic chicken & 3.47 & 0.013 & 0.045 \\
11 & Donkey & 1.49 & 0.70 & 1.043 \\
12 & Horse & 1.21 & 1.10 & 1.331 \\
& Total & & & 10.74 \\
\hline
\end{tabular}

West Arsi Zone has only about 2.35 percent of crossed breed compared to local breeds (Table 6). Even though there is high livestock potential, activity done so far to improve livestock breed in West Arsi Zone not enough as required.

To classify livestock in terms of their keeping purpose, oxen and bull were kept for draught power, social values (prestige and wedding ceremony) and fattening purposes while cows and heifers cattle were kept for breeding purposes, milk production and social values in the study areas. The mean milk production per household in West Arsi Zone was around 2 liters per a household per day during feeding shortage. The milk productivity obtained from local cows and cross breed cows were 1.10 liter/day/cow and 2.88 liter/day/cow during feed shortage respectively. But, the mean milk productivity obtained from local cows and crossed breed cows were 2.27 liters/day/cow and 5.40 liters/day/cow respectively during feed availability. Therefore, working on all aspects of the dairy cows like availing feed and provide health service can increase the production and productivity that obtain from dairy production. Furthermore, livestock provide sources of manure and fuel, organic fertilizers and saving for households to buffer bleak seasons of food/seed shortage especially in highland and midland areas of West Arsi Zone that supported by the findings [4].

Pack animals (donkey, horses and mules) were important means of transportation in farm and non-farm activities (petty trading); productive and reproductive activities and both for human and agricultural products.

Small ruminants were kept for immediate/emergency cash obligations, unplanned emergency issues, educating children, to purchase agricultural inputs like fertilizer, seed and chemicals as well as to pay land tax which is supported by the finding [12]. While poultry birds were mostly owned by children and female spouses and used for household consumption and selling to markets to purchase the households' consumables which were non-agricultural products.

\subsection{Major Livestock Production Constraints in West Arsi Zone}

The index rank result indicates that the major livestock production constraints were identified as lack of access to credit services, shortage of improved breed, lack of improved technologies like artificial insemination (AI), shortage of feed, disease, and climate change. Feed shortage and livestock diseases are among the major constraints which hampered the expansion of small-holder livestock production which is confirmed by the findings [8, 12]. Lack of credit, lack of market information and poor access to extension service were also another major livestock production constraint in West Arsi Zone. This result is supported by the findings $[13,14]$.

Table 7. Major livestock production constraints in West Arsi Zone.

\begin{tabular}{|c|c|c|c|c|c|c|c|c|c|c|}
\hline \multirow{2}{*}{ No } & \multirow{2}{*}{ Major Constraints } & \multicolumn{2}{|l|}{$1^{\text {st }}$} & \multicolumn{2}{|l|}{$2^{\text {nd }}$} & \multicolumn{2}{|l|}{$3^{\text {rd }}$} & \multicolumn{2}{|l|}{$4^{\text {th }}$} & \multirow{2}{*}{ Index Rank } \\
\hline & & Freq. & $\%$ & Freq. & $\%$ & Freq. & $\%$ & Freq. & $\%$ & \\
\hline 1 & Lack of credit & 29 & 11.03 & 72 & 28.57 & 47 & 22.38 & 27 & 27.27 & 1 \\
\hline 2 & Lack of improved breed & 54 & 20.53 & 56 & 22.22 & 34 & 16.19 & 10 & 10.10 & 2 \\
\hline 3 & Shortage of feed & 41 & 53.61 & 37 & 14.68 & 23 & 10.95 & 11 & 11.11 & 3 \\
\hline 4 & Poor access to extension service & 13 & 4.94 & 28 & 11.11 & 39 & 18.57 & 20 & 20.20 & 4 \\
\hline 5 & Lack of market information & 8 & 3.04 & 14 & 5.56 & 27 & 12.86 & 18 & 18.18 & 5 \\
\hline 6 & Lack of technologies & 3 & 1.14 & 16 & 6.35 & 12 & 5.71 & 3 & 3.03 & 6 \\
\hline 8 & Disease & 8 & 3.04 & 10 & 3.97 & 11 & 5.24 & 1 & 1.01 & 8 \\
\hline
\end{tabular}

Source: household survey and FGD results, 2016.

A study conducted in southern Ethiopia which support this study, reported that households have experienced a severe reduction in their assets, with an average reduction of $80 \%$ in livestock holdings from their peak holdings over the past ten years mainly by climate change [15].

\section{Conclusion and Policy Implication}

Livestock production plays an important role in generating income for farmers in West Arsi Zone, Ethiopia. Based on the 
agro-ecology and livestock production dominance, the livestock production system is classified into two categories. This classification are mixed rainfall sufficient (MRS) which cattle, equine and sheep production dominantly undertaken and mixed rainfall deficit (MRD) which is dominant in goat, beekeeping and backyard poultry production dominantly undertaken.

Livestock production in West Arsi Zone was constrained by different factors. Among the constraints that affect livestock production are lack of credit, lack of improved breed, shortage of feed, poor extension service, lack of market information, lack of livestock technologies, climate change and livestock diseases. The knowledge gap as a constraint was found to be critical for respondents who owned poultry, haven't access and demand for improved forage and veterinary service, respectively. Therefore, based on the study finding addressing farmers demand for improved breeds, forage technologies and in provision of training or improved health managements may address the smallholder famers' burdens in the area. All concerned governmental and non-governmental organizations that have working in the area must focus to work on and plan their efforts accordingly. Through these considerations, it may possible to bring considerable impact in the livestock production sub-system of the area in general and the livelihood of the farming community in particular.

\section{Acknowledgements}

The author is grateful to respondent farmers at the selected districts of West Arsi Zone who spent their valuable time to provide information during the focus group discussion and survey data collection periods. Thanks also to the local authorities, Zone and districts agriculture and natural resource office staffs, for their help during whole study period and in provision of secondary information.

\section{References}

[1] FAO, 2016. Ethiopia Climate-Smart Agriculture Scoping Study. Addis Ababa, Ethiopia.

[2] Guo R., Brhane Weldegebrial, Genet Yohannes, Gebremedhin Yohannes, 2018. Climate Change Adaptation Practices by Ruminant Livestock Producer of in Hintalo Wajerat District Tigray Regional State, Northern Ethiopia. Biomed J Sci \& Tech Res., pp. 20-21.
[3] FAO, 2010. Greenhouse gas emissions from the dairy sector. A life cycle assessment. A report prepared by Food and Agriculture Organization of the United Nations animal production and health division, FAO, Rome.

[4] Shapiro, B. I., Gebru, G., Desta, S., Negassa, A., Nigussie, K., Aboset G. and Mechale. H., 2017. Ethiopia livestock sector analysis. International Livestock Research Institute (ILRI) Project Report. Nairobi, Kenya.

[5] EIAR (Ethiopian Institute of Agricultural Research), 2012. Forage Seed Research and Development, Addis Ababa, Ethiopia.

[6] CSA (Center Statistical Agency), 2013 2016/17. Agricultural sample survey report on livestock and livestock characteristics (private peasant holdings), Volume II. Addis Ababa, Ethiopia.

[7] Belachew H, Jemberu E., 2002. Challenges and opportunities of livestock marketing in Ethiopia, Challenges and opportunities of livestock marketing in Ethiopia. Proceedings of the 10th annual conference, Ethiopia Society of Animal production (ESAP), Addis Ababa, Ethiopia, Pp 1-13.

[8] Belay D., Getachew E., Azage T., and Hegde B. H., 2013. Farmers' perceived livestock production constraints in Ginchi watershed area: Result of participatory rural appraisal, International Journal of Livestock Production, Vol. 4 (8), pp. 128-134.

[9] Eyob Eshetu, and Zewudu Abraham, 2016. Review on live animal and meat export marketing system in Ethiopia: challenges and opportunities, Journal of Scientific and Innovative Research; 5 (2): 59-64.

[10] ZOANR (Zonal Office of Agriculture and Natural Resource), 2016. Reports of West Arsi Zone Office of Agriculture and Natural Resource, Shashemene, Ethiopia, unpublished.

[11] Food Agricultural Organisation (FAO), 2007. Climate Change: Climate Change Impacts, Adaptation and Vulnerability. IPCC WG II Forht Assessment Report.

[12] Abate Feyissa, 2009. Climate Change Impact on Livelihood, Vulnerability and Coping Mechanisms: A Case Study of WestArsi Zone, Ethiopia. LUCSUS, Lund University SE-22644, Lund, Sweden.

[13] Mohammed AA, Ehui S, Yemesrach A., 2004. Diary Development in Ethiopia. EPTD discussion paper No. 123.

[14] Workneh Abebe, 2007. Determinants of Adoption of Improved Box Hive in Atsbi Wemberta District of Eastern Zone, Tigray Region. MSc Thesis, Haramaya University, Ethiopia, pp: 63.

[15] Shambel Bekele, 2017. Impacts of Climate Change on Livestock Production: A Review, Journal of Natural Sciences Research, Vol. 7, No. 8, pp. 56. 